\title{
Non-gastric marginal zone B cell lymphoma: clinicopathologic features and treatment results
}

\author{
Harinder Gill • Chor-Sang Chim • Wing-Yan Au • \\ Florence Loong • Eric Tse • Anskar Y. H. Leung • \\ Yok-Lam Kwong
}

Received: 13 December 2010/Accepted: 22 March 2011/Published online: 8 April 2011

(C) The Author(s) 2011. This article is published with open access at Springerlink.com

\begin{abstract}
The optimal treatment strategy and outcome of nongastric marginal zone lymphoma (MZL) remains undefined. The role of rituximab and fludarabine in MZL has not been critically appraised and compared with conventional chemotherapy. We retrospectively analyzed 81 consecutive patients with non-gastric MZL (mucosa-associated lymphoid tissue lymphoma, $n=66$; splenic MZL, $n=11$; nodal MZL, $n=4)$. As a group, the treatment results were favorable, with an overall response rate of $87 \%$ and a complete response (CR) rate of $73 \%$. The CR rate was similar for conventional chemotherapy, and rituximab- and fludarabine-containing regimens. However, the relapse rate was significantly decreased in rituximab- and fludarabine-containing regimens. The use of rituximab and fludarabine was associated with acceptable side effects. For splenic MZL, splenectomy was significantly associated with a superior CR rate. Early stage, good performance status, and low international prognostic index risk scores significantly impacted on $\mathrm{CR}$ rate and survivals. Rituximab and fludarabine were safe for non-gastric MZL and resulted in more durable remissions.
\end{abstract}

Keywords Non-gastric marginal zone lymphoma.

Mucosa-associated lymphoid tissue $\cdot$ Splenic marginal zone lymphoma $\cdot$ Rituximab $\cdot$ Fludarabine

H. Gill • C.-S. Chim • W.-Y. Au • E. Tse • A. Y. H. Leung •

Y.-L. Kwong $(\triangle)$

Department of Medicine, Professorial Block,

Queen Mary Hospital,

Pokfulam Road,

Hong Kong, China

e-mail: ylkwong@hkucc.hku.hk

F. Loong

Department of Pathology, Queen Mary Hospital,

Hong Kong, China

\section{Introduction}

The World Health Organization (WHO) classification of lymphoid malignancies distinguishes between three different subtypes of marginal zone B cell lymphomas: splenic B cell marginal zone lymphoma (splenic MZL) [1], extranodal marginal zone lymphoma of mucosaassociated lymphoid tissue (MALT lymphoma) [2], and nodal marginal zone lymphoma (nodal MZL) [3]. MZLs are derived putatively from memory B cells that have passed through the germinal center (post-germinal center memory B cells) [4]. The lymphoma cells, similar to their putative normal counterparts, possess a remarkable capability to home to sites where they have undergone antigenic stimulation, including MALT, the spleen, and lymph nodes [5], accounting for the formation of lymphomas in these sites. However, despite a common cell origin, MZL originating at different anatomical sites have distinct clinicopathologic features and treatment outcome [1-3].

Infections or chronic inflammation may provide the antigenic stimulation in the initial stages of lymphomagenesis. Relevant infections include Helicobacter pylori in gastric MALT lymphoma, Campylobacter jejuni, Borrelia burgdorferi, and Chlamydia psittaci in extranodal MZL, and hepatitis $\mathrm{C}$ virus in splenic MZL [6]. Chronic inflammation due to autoimmune diseases, commonly involving Sjögren syndrome and Hashimoto thyroiditis, also predisposes to extranodal MZL [6].

MZLs are considered low-grade lymphomas. Gastric MALT lymphoma is the most common MZL. The efficacy of $H$. pylori eradication and the subsequent therapeutic strategies for gastric MZL have been well defined [7]. For non-gastric MZL, however, the optimum 
treatment is less well established because most large series contained a mixture of gastric and non-gastric MZL and rarely analyzed these disease entities separately.

Two classes of drugs, rituximab and purine analogues (including fludarabine and 2-chlorodeoxyadenosine), have made a major positive impact on the treatment outcome of low-grade lymphomas, particularly follicular lymphoma. However, their efficacy in the management of MZL has only recently been examined [8-11], although their role in comparison with other conventional regimens is still undefined.

In this study, we retrospectively analyzed a consecutive cohort of patients with non-gastric MZL in order to define the clinicopathologic features and the role of rituximab and the purine analogue fludarabine in comparison with alkylating agents in the treatment of these lymphomas. Although there is as yet no definitive evidence that non-gastric MZL, splenic MZL, and nodal MZL are distinctive diseases, increasing evidence suggests that they have different clinicopathologic features and treatment outcome. Therefore, they were also both analyzed individually and together as a group in this study.

\section{Materials and methods}

\section{Patients}

Consecutive patients with non-gastric MZL diagnosed between January 1998 and January 2010 were analyzed. There were no exclusion criteria. The diagnoses were based on the WHO classification criteria of MZL [1-3].

\section{Investigations and treatment}

Standard staging procedures including bilateral bone marrow trephine biopsies were adopted. Computerized tomography, magnetic resonance imaging, or positron emission tomography/computerized tomography was used for the detection of organ or tissue involvement at the primary site, thorax and abdomen. Treatment regimens were determined at the discretion of the attending physicians.

\section{Statistical analysis}

Response to treatment was determined by standard criteria [12]. Overall survival (OS) was calculated from the date of diagnosis to the date of death or last follow-up. Disease-free survival (DFS) was calculated from the date of achievement of complete response to date of death, disease relapse/progression, or date of last follow-up.
Difference between treatment groups was calculated by chi-square test. Prognostic factors for complete response (CR) and mortality were identified with logistic regression analysis. Five-year OS and DFS were estimated through the Kaplan-Meier method, and comparisons between treatment regimens were performed using Cox regression analysis.

\section{Results}

Patients

Eighty-one patients were identified (Table 1). There was no gender preference, with a median age of presentation at 57 (15-86)years. MALT lymphomas were most prevalent, followed by splenic and nodal MZL. Patients predominantly presented with early-stage disease, with good performance status and no B symptoms. Therefore, the majority of patients had favorable International Prognostic Index (IPI) scores. Paraproteins were present in 15 of 81 (18\%) patients. About $20 \%$ of patients had a known underlying autoimmune disease. Chronic hepatitis B virus infection was found in $17 \%$ of patients, which was comparable with the general population. Hepatitis C infection was only found in one patient. Notably, two of the patients were siblings, having splenic and nodal MZL, respectively.

\section{Non-gastric MALT lymphoma}

Sixty-six patients had MALT lymphomas (Table 2). Early-stage (stage I/II) disease was found in $80 \%$ of patients. The most common sites of presentation were ocular and ocular adnexal structures (29\%), followed by the salivary glands $(20 \%)$. Multiple sites of involvement were found in eight patients (12\%). None of the patients with ocular MALT lymphoma had autoimmune disorders. However, seven patients with salivary gland (11\%) and two patients with thymic involvement (4\%) had underlying Sjögren syndrome. All four patients with thyroid MALT lymphoma had autoimmune thyroiditis with hypothyroidism. Autoimmune thyroid disease was also found in a patient with skin MALT lymphoma. Other associations were mixed connective tissue disease in a patient with submandibular involvement and Graves' disease in a patient with conjunctival involvement. Therefore, the frequency of autoimmune diseases in this group of patient was $24 \%(16 / 66)$. A monoclonal paraprotein was detected in 12 patients $(18 \%)$. Whereas immunoglobulin ( $\mathrm{Ig}$ ) $\mathrm{M}$ and $\mathrm{G}$ were found in MALT lymphoma in various sites, IgA was detected only in two patients with thymic involvement. 
Table 1 Clinicopathological features of 81 patients with marginal zone lymphoma

\begin{tabular}{|c|c|}
\hline Clinicopathological features & Number $(\%)$ \\
\hline \multicolumn{2}{|l|}{ Gender } \\
\hline Male & $38(47)$ \\
\hline Female & $43(53)$ \\
\hline Median age (range), years & $57(15-86)$ \\
\hline \multicolumn{2}{|l|}{ Diagnosis } \\
\hline Non-gastric MALT lymphoma & $66(81)$ \\
\hline Splenic marginal zone B cell lymphoma & $11(14)$ \\
\hline Nodal marginal zone lymphoma & $4(5)$ \\
\hline \multicolumn{2}{|l|}{ Ann Arbor stage } \\
\hline I & $41(51)$ \\
\hline II & $13(16)$ \\
\hline III & $5(6)$ \\
\hline IV & $22(27)$ \\
\hline Presence of B symptoms & $6(7)$ \\
\hline \multicolumn{2}{|l|}{ Performance status } \\
\hline 0 & $46(57)$ \\
\hline 1 & $21(26)$ \\
\hline 2 & $11(13)$ \\
\hline 3 & $3(4)$ \\
\hline 4 & $0(0)$ \\
\hline \multicolumn{2}{|l|}{ International prognostic index } \\
\hline Low $(0$ or 1$)$ & $35(43)$ \\
\hline Low/intermediate (2) & $23(28)$ \\
\hline Intermediate/high (3) & $16(20)$ \\
\hline High (4 or 5 ) & $7(9)$ \\
\hline \multicolumn{2}{|l|}{ Lactate dehydrogenase } \\
\hline Increased & $65(80)$ \\
\hline Normal & $14(17)$ \\
\hline Not available & $2(3)$ \\
\hline \multicolumn{2}{|l|}{ Paraprotein } \\
\hline Immunoglobulin $\mathrm{G}$ & $4(5)$ \\
\hline Immunoglobulin $\mathrm{M}$ & $6(7)$ \\
\hline Immunoglobulin A & $2(2)$ \\
\hline Two monoclonal antibodies & $3(4)$ \\
\hline Not present & $60(74)$ \\
\hline Not available & $6(7)$ \\
\hline \multicolumn{2}{|l|}{ Hepatitis B virus infection } \\
\hline Positive & $14(17)$ \\
\hline Negative & $64(79)$ \\
\hline Not available & $3(4)$ \\
\hline \multicolumn{2}{|l|}{ Concomitant autoimmune disorders } \\
\hline Present & $18(22)$ \\
\hline Absent & $63(79)$ \\
\hline
\end{tabular}

\section{Splenic MZL}

Eleven patients (nine men, two women) had splenic MZL (Table 3). Moderate splenomegaly (median size $10 \mathrm{~cm}$
Table 2 Clinicopathological features of 66 patients with non-gastric MALT lymphoma

Clinicopathological features

Number (\%)

\section{Gender}

Male

$27(41)$

Female

$39(59)$

Median age (range), years

$57(15-86)$

Primary site(s) of presentation

Ocular and ocular adnexae

Salivary gland

Buccal mucosa

Nasopharynx

1 (2)

Cricoid

1 (2)

Tonsils

1 (2)

Thyroid gland

4 (6)

Thymus

1 (2)

Lungs

$6(9)$

Intestine

$5(8)$

Omentum

1 (2)

Testes

Cutaneous

$3(5)$

Two or more anatomical sites

Ann Arbor stage

I

II

III

IV

International Prognostic Index

Low (0 or 1$)$

Low/intermediate (2)

Intermediate/high (3)

$2(3)$

High (4 or 5)

$0(0)$

Paraprotein

Immunoglobulin $\mathrm{G}$

$3(5)$

Immunoglobulin $\mathrm{M}$

Immunoglobulin A

Two monoclonal antibodies

Not present

49 (74)

Not available

Associated autoimmune diseases

Sjögren syndrome 9 (14)

Parotid MALT lymphoma 4 (6)

Submandibular MALT lymphoma 1 (2)

Minor salivary gland MALT lymphoma 2 (3)

Thymic MALT lymphoma 1 (2)

Multifocal MALT lymphoma involving also the thymus 1 (2)

Autoimmune thyroiditis with hypothyroidism 5 (8)

Thyroid MALT lymphoma 4 (6)

Cutaneous MALT lymphoma 1 (2)

Mixed connective tissue disease 1 (2)

Submandibular MALT lymphoma 1 (2)

Graves' disease

$1(2)$

Conjunctival MALT lymphoma 
Table 3 Clinicopathologic features and treatment results of 11 patients with splenic marginal zone lymphoma

\begin{tabular}{|c|c|}
\hline Parameters & Number $(\%)$ \\
\hline \multicolumn{2}{|l|}{ Gender } \\
\hline Male & $9(82)$ \\
\hline Female & $2(18)$ \\
\hline Median age (range), years & $50(35-80)$ \\
\hline B symptoms & $3(27)$ \\
\hline Splenomegaly & $11(100)$ \\
\hline Median size (range), $\mathrm{cm}$ below left costal margin & $10\left(\begin{array}{ll}5 & 25\end{array}\right)$ \\
\hline Hepatomegaly & $2(18)$ \\
\hline \multicolumn{2}{|l|}{ Hematological parameters } \\
\hline Anemia $(\mathrm{Hb}<11 \mathrm{~g} / \mathrm{dL})$ & $7(64)$ \\
\hline Lymphocytosis $\left(>4 \times 10^{9} / \mathrm{L}\right)$ & $5(45)$ \\
\hline Neutropenia $\left(<2 \times 10^{9} / \mathrm{L}\right)$ & $2(18)$ \\
\hline Thrombocytopenia $\left(<100 \times 10^{9} / \mathrm{L}\right)$ & $5(45)$ \\
\hline Leukemic phase & $5(55)$ \\
\hline Marrow infiltration & $11(100)$ \\
\hline \multicolumn{2}{|l|}{ Paraproteinemia } \\
\hline $\operatorname{IgG}$ & $1(9)$ \\
\hline $\operatorname{IgM}$ & $1(9)$ \\
\hline \multicolumn{2}{|l|}{ International prognostic index } \\
\hline Low $(0$ or 1$)$ & $1(9)$ \\
\hline Low/intermediate (2) & $3(27)$ \\
\hline Intermediate/high (3) & $5(45)$ \\
\hline High (4 or 5$)$ & $2(18)$ \\
\hline \multicolumn{2}{|l|}{ Treatment and outcome } \\
\hline Splenectomy + chemotherapy $^{\mathrm{a}}$ & $3(27)$ \\
\hline $\mathrm{CR}$ & $2 / 3(67)$ \\
\hline PR & $1 / 3(33)$ \\
\hline Splenectomy + rituximab + chemotherapy $^{a}$ & $2(18)$ \\
\hline $\mathrm{CR}$ & $2 / 2(100)$ \\
\hline Chemotherapy $^{\mathrm{a}}$ & $5(45)$ \\
\hline $\mathrm{CR}$ & $1 / 5(20)$ \\
\hline NR & $4 / 5(80)$ \\
\hline Chemotherapy $^{\mathrm{a}}+$ rituximab & $1(9)$ \\
\hline PR & $1 / 1(100)$ \\
\hline
\end{tabular}

$I g$ immunoglobulin, $C R$ complete response, $P R$ partial response, $N R$ no response

${ }^{a}$ Chemotherapy included chlorambucil, FND (fludarabine, mitoxantrone, dexamethasone), CHOP (cyclophosphamide, doxorubicin, vincristine, prednisolone), CEOP (cyclophosphamide, epirubicin, vincristine, prednisolone), and M-BACOD (methotrexate, bleomycin, doxorubicin, cyclophosphamide, vincristine, dexamethasone)

below costal margin) was found in all the cases. There were varying degrees of peripheral blood cytopenias. Although neoplastic infiltration of the marrow was observed in all patients, circulating lymphoma cells were detectable in only six patients $(55 \%)$. Monoclonal immunoglobulin was detected in two patients (18\%).
One patient was positive for lupus anticoagulant. In one patient, the lymphoma cells were positive for CD5 with an absolute lymphocytosis of $10.8 \times 10^{9} / \mathrm{L}$ at presentation.

Nodal MZL

There were four patients (two men, two women) with NMZL. IgM monoclonal protein was detected in one patient. In one patient, there was coexisting autoimmune hemolytic anemia, vitiligo, and common variable immunodeficiency diagnosed prior to the occurrence of NMZL.

Treatment outcome of non-gastric MZL

Local therapy (excision with or without involved field radiotherapy) was administered in 17 patients (26\%). Twenty-seven patients (41\%) received systemic chemotherapy. Twelve patients (18\%) received rituximab-containing chemotherapeutic regimens. Eight patients (12\%) received rituximab alone. The response rates for this group of patients were presented in Table 4.

Splenic MZL

The treatment regimens and responses for this group of patients were presented in Table 3. Splenectomy was performed in five patients, which was followed by chemotherapy in three patients and rituximab and chemotherapy in two patients. Six patients received chemotherapy without splenectomy, one of whom received rituximab as well. The CR rate was significantly better in patients who were splenectomized as compared with those who were not (CR: $4 / 5$ splenectomized versus $1 / 6$ nonsplenectomized, $P=0.035$ ).

Nodal MZL

Two patients were treated with the regimen fludarabine, mitoxantrone, dexamethasone (FND): one patient with RFND (rituximab $375 \mathrm{mg} / \mathrm{m}^{2}$ before each course of FND) and one patient with chlorambucil followed by rituximab ( $375 \mathrm{mg} / \mathrm{m}^{2}$ given weekly for four doses). CR was achieved in two patients and partial response (PR) in one patient.

Relapse characteristics and transformation

The features and outcome of relapsed cases of the nongastric, splenic, and nodal MZL were presented individually in Table 5. Fifteen patients with non-gastric MALT lymphoma relapsed, three with high-grade histological transformation. Ten patients underwent further treatment, 
Table 4 Treatment and outcome of 66 patients with non-gastric MALT lymphoma

\begin{tabular}{|c|c|}
\hline Treatment and outcome & Number $(\%)$ \\
\hline Refused treatment or defaulted & $2(3)$ \\
\hline Local resection only & $11(17)$ \\
\hline $\mathrm{CR}$ & $8 / 11(73)$ \\
\hline PR & $0 / 11(0)$ \\
\hline NR & $3 / 11(27)$ \\
\hline Radiotherapy alone & $3(5)$ \\
\hline $\mathrm{CR}$ & $3 / 3(100)$ \\
\hline PR & $0 / 3(0)$ \\
\hline NR & $0 / 3(0)$ \\
\hline Local resection + radiotherapy & $3(5)$ \\
\hline $\mathrm{CR}$ & $3 / 3(100)$ \\
\hline PR & $0 / 3(0)$ \\
\hline NR & $0 / 3(0)$ \\
\hline Rituximab \pm local treatment & $8(12)$ \\
\hline $\mathrm{CR}$ & $7 / 8(88)$ \\
\hline $\mathrm{PR}$ & $1 / 8(12)$ \\
\hline NR & $0 / 8(0)$ \\
\hline Chemotherapy \pm local treatment & $27(41)$ \\
\hline $\mathrm{CR}$ & 20/27 (74) \\
\hline PR & $5 / 27(19)$ \\
\hline NR & $2 / 27(7)$ \\
\hline Rituximab + chemotherapy \pm local treatment & $12(18)$ \\
\hline $\mathrm{CR}$ & $10 / 12(83)$ \\
\hline PR & 2/12 (17) \\
\hline NR & $0 / 12(0)$ \\
\hline
\end{tabular}

$C R$ complete response, $P R$ partial response, $N R$ no response

with nine $(90 \%)$ achieving a second CR. The only patient who did not respond to treatment had small bowel and pleural involvement, which at relapse showed transformation into diffuse large B cell lymphoma. Of the nine cases achieving CR2, two patients had subsequent relapses, presenting as transformation into high-grade follicular lymphoma and diffuse large B cell lymphomas. Both patients died ultimately of refractory lymphoma despite intensive chemotherapy and hematopoietic stem cell transplantation. Three patients with splenic MZL relapsed, two of whom showed high-grade histological transformation. Only one patient achieved a CR2 after intensive chemotherapy and allogeneic hematopoietic stem cell transplantation. One patient with nodal MZL relapsed as a high-grade lymphoma and achieved CR after chemotherapy and ibritumomab tiuxetan therapy.

\section{Toxicity of treatment}

Grade 4 neutropenia and febrile neutropenia was encountered in $14(17.3 \%)$ and $13(16 \%)$ patients, respectively (Table 6). Treatment-related mortality due to sepsis oc- curred in two cases $(2.5 \%)$. Therapy-related acute myeloid leukemia developed in one patient with parotid MALT lymphoma 6 years after diagnosis.

\section{Prognostic factors}

Treatment results of the entire group were shown in Table 7. The overall response rate was $87 \%$ (69/79 patients) with a CR of $73 \%$ (58/79 patients). Various regimens designed for indolent lymphomas were used (Table 8). Fludarabine regimens and non-fludarabine regimens did not impact on $\mathrm{CR}$ rates. However, relapses were significantly reduced in patients receiving fludarabine regimens as compared with those receiving non-fludarabine regimens $(3 / 23,13 \%$ versus $9 /$ $22,41 \%, P=0.03)$. Interestingly, rituximab-containing regimens and non-rituximab regimens also did not impact on CR rates. However, relapses were significantly decreased in patients receiving rituximab-containing regimens as compared with those receiving non-rituximab regimens $(2 / 21$, $10 \%$ versus $10 / 24,42 \%, P=0.015)$. Similarly, when these regimens were analyzed according to whether fludarabine and/or rituximab were used, the CR rates were comparable. However, relapse rates were significantly lower in patients receiving both rituximab and fludarabine as compared with patients receiving none $(P=0.008)$, while patients receiving either rituximab or fludarabine showed intermediate results (Table 8). The impact of stage, performance status, and IPI risk score on response rates was evaluated using logistic regression. Favorable prognostic factors for $\mathrm{CR}$ were earlystage (stage $\mathrm{I} / \mathrm{II})$ disease $(\mathrm{OR}=3.11, P=0.039)$, good performance status $(\leq 1, \mathrm{OR}=9.36, P<0.001)$, and low IPI risk score $(<3, \mathrm{OR}=4.17, P=0.011)$. These factors, nevertheless, did not impact on the relapse rates.

\section{Survivals}

The 5-year OS for the whole cohort was $84.6 \%(95 \%$ confidence interval, $\mathrm{CI}=0.73-0.92$; Fig. 1a) and the 5-year DFS was $82.2 \%(95 \% \mathrm{CI}=0.70-0.90$; Fig. 1b). During the follow-up period, 14 patients (non-gastric MZL, $n=9$; splenic MZL, $n=5$ ) died: ten from refractory diseases, two from treatment-related causes, one from therapy-related leukemia, and one from unrelated causes. Prognostic factors associated with a lower mortality included stage I/II disease (odds ratio $=0.08, P<0.001$ ) and IPI risk score $<3$ (odds ratio $=0.09, P<0.001$ ). No differences in survival or mortality were observed between different treatment regimens.

\section{Discussion}

In this study, we have analyzed a cohort of MZL patients separately according to whether they had non-gastric, 
Table 5 Clinicopathological features and outcome of 19 patients with relapsed non-gastric marginal zone lymphoma

\begin{tabular}{|c|c|}
\hline Clinicopathological features and outcome & Number $(\%$ \\
\hline Non-gastric MALT lymphoma & $15 / 66(23)$ \\
\hline \multicolumn{2}{|l|}{ Site of relapse } \\
\hline Same & $8(53)$ \\
\hline Different & $7(47)$ \\
\hline \multicolumn{2}{|l|}{ Pattern of relapse } \\
\hline Locoregional & $8(53)$ \\
\hline Advanced/disseminated & $7(47)$ \\
\hline \multicolumn{2}{|l|}{ Transformation } \\
\hline None & $63 / 66(95)$ \\
\hline Diffuse large B cell lymphoma & $2 / 66(3)$ \\
\hline High-grade follicular lymphoma & $1 / 66(2)$ \\
\hline \multicolumn{2}{|l|}{ Treatment and outcome } \\
\hline Radiotherapy alone & 1 \\
\hline $\mathrm{CR}$ & $1 / 1(100)$ \\
\hline Radiotherapy+FND & 1 \\
\hline $\mathrm{CR}$ & $1 / 1(100)$ \\
\hline Excision + radiotherapy + rituximab & 1 \\
\hline $\mathrm{CR}$ & $1 / 1(100)$ \\
\hline Excision+R-COPP & 1 \\
\hline $\mathrm{CR}$ & $1 / 1(100)$ \\
\hline FND & 2 \\
\hline $\mathrm{CR}$ & $2 / 2(100)$ \\
\hline CEOP & 1 \\
\hline $\mathrm{CR}$ & $1 / 1(100)$ \\
\hline NOPP & 1 \\
\hline NR & $1 / 1(100)$ \\
\hline $\begin{array}{l}\text { CEOP followed by autologous PBSCT } \\
\text { consolidation }\end{array}$ & 1 \\
\hline $\mathrm{CR}$ & $1 / 1(100)$ \\
\hline $\begin{array}{l}\text { DHAP followed by autologous PBSCT } \\
\text { consolidation }\end{array}$ & 1 \\
\hline $\mathrm{CR}$ & $1 / 1(100)$ \\
\hline Splenic marginal zone lymphoma & 3/11 (27) \\
\hline \multicolumn{2}{|l|}{ Site of relapse } \\
\hline Same & $3(100)$ \\
\hline \multicolumn{2}{|l|}{ Pattern of relapse } \\
\hline Advanced/disseminated & $3(100)$ \\
\hline \multicolumn{2}{|l|}{ Transformation } \\
\hline Diffuse large B cell lymphoma & $1 / 11(9)$ \\
\hline T cell-rich B cell lymphoma & $1 / 11(9)$ \\
\hline \multicolumn{2}{|l|}{ Treatment and outcome } \\
\hline FND & 1 \\
\hline PR & $1 / 1(100)$ \\
\hline CEOP & 1 \\
\hline NR & $1 / 1(100)$ \\
\hline $\begin{array}{l}\text { DHAP followed by matched sibling } \\
\text { allogeneic BMT }\end{array}$ & 1 \\
\hline $\mathrm{CR}$ & $1 / 1(100)$ \\
\hline
\end{tabular}

Table 5 (continued)

\begin{tabular}{ll}
\hline Clinicopathological features and outcome & Number (\%) \\
\hline $\begin{array}{l}\text { Nodal marginal zone lymphoma } \\
\text { Site of relapse }\end{array}$ & $1 / 4(25)$ \\
Same & $1(100)$ \\
Pattern of relapse & \\
Advanced/disseminated & $1(100)$ \\
Transformation & $1 / 4(25)$ \\
Diffuse large B cell lymphoma & $1 / 4(25)$ \\
Treatment and outcome & 1 \\
R-CEOP followed by ${ }^{90}$ Y-irbitumomab & \\
tiuxetan consolidation & $1 / 1(100)$ \\
CR &
\end{tabular}

$C R$ complete response, $P R$ partial response, $N R$ no response, $F N D$ fludarabine-mitoxantrone-dexamethasone, CEOP cyclophosphamide-epirubicin-vincristine-prednisolone, NOPP mitoxantrone-vincristine-procarbazine-prednisolone, DHAP dexamethasonecytarabine-cisplatin, $C O P P$ cyclophosphamide-vincristine-procarbazine-prednisolone, $P B S C T$ peripheral blood stem cell transplantation, $B M T$ bone marrow transplantation, $R$ rituximab at $375 \mathrm{mg} / \mathrm{m}^{2}$ before each course of chemotherapy

splenic, and nodal disease and also as a group for their responses to treatment. The reason for analyzing three MZL as a group with respect to treatment outcome is because similar drugs and strategies are often employed in their treatment. This series showed features characteristic of MZL. There was a slight female predominance (women/ men $=1.4: 1$ ), probably related to a higher frequency of autoimmune diseases in women, which predisposes to MZL. In fact, the association of non-gastric MALT lymphomas with autoimmune diseases was clearly observed [13, 14], including salivary gland and thymic MALT lymphomas with Sjögren's syndrome and thyroid MALT lymphomas with autoimmune thyroiditis. The most common primary site was ocular and ocular adnexal structures, followed by salivary glands and lungs, similar to previously reported findings $[15,16]$. About $30 \%$ of patients had stage IV disease at presentation, often with multiple sites of involvement, which is in contrast to gastric MALT lymphomas that are usually localized [17].

For the whole cohort, treatment results were favorable, with CR achieved in $73 \%$ of patients. The impact of surgical removal of the lymphoma, particularly in localized non-gastric MALT lymphomas in the salivary and thyroid glands, has not been fully evaluated. We showed that splenectomy, even in our small series of splenic MZL, had a significantly favorable impact on CR. Splenectomy has traditionally been considered to be an important first-line treatment for splenic MZL [18]. However, with the advent of effective drugs including rituximab and fludarabine, the role of splenectomy has 
Table 6 Therapy-related toxicities in 81 patients with non-gastric marginal zone lymphomas

\begin{tabular}{lc}
\hline Toxicity & Number (\%) \\
\hline Anemia & \\
Grade 1 & $10(12)$ \\
2 & $6(7)$ \\
3 & $3(4)$ \\
4 & $2(3)$ \\
Neutropenia & \\
Grade 1 & $5(6)$ \\
2 & $4(5)$ \\
3 & $10(12)$ \\
4 & $14(17)$ \\
Thrombocytopenia & \\
Grade 1 & $1(1)$ \\
2 & $3(4)$ \\
3 & $4(5)$ \\
4 & $8(10)$ \\
Intracranial hemorrhage & $1(1)$ \\
Febrile neutropenia & $13(16)$ \\
Bacteraemia & $9(11)$ \\
Invasive fungal infections & $1(1)$ \\
Reactivation of tuberculosis & $1(1)$ \\
Localized herpes zoster & $1(1)$ \\
Disseminated herpes zoster & $1(1)$ \\
Reactivation of hepatitis B virus infection & $1(1)$ \\
Mherapy-related acute myeloid leukemia & $1(1)$ \\
Therapy-related mortality & $4(5)$ \\
\hline & $2(3)$ \\
\hline
\end{tabular}

${ }^{a}$ Including two cases of vincristine-related neuropathy, one case of chlorambucil-related liver function derangement, and one case of acute graft-versus-host disease of the skin after matched sibling bone marrow transplantation been questioned [19]. In a recent series of splenic MZL, the purine analogue 2-chlorodeoxyadenosine with or without rituximab has been reported to result in a CR rate of only $52 \%$, very few of the patients having undergone a splenectomy [11]. The role of splenectomy might be clarified by a trial comparing splenectomy + immunochemotherapy versus immunochemotherapy alone. However, such a study is unlikely to be performed because of the rarity of splenic MZL and the general reluctance of using surgery to treat lymphoma patients. Hence, it may not be unreasonable to start treatment with a combination of rituximab and a purine analogue and reserve the more invasive splenectomy for patients with unsatisfactory responses or relapses after immunochemotherapy.

Similarly, although rituximab has significantly improved the outcome of aggressive [20] and indolent [21] B cell lymphomas, its role in MZL has not been critically appraised. If fact, data of the impact of rituximab on the outcome of MZL have not been well documented. Likewise, whereas purine analogues have improved the treatment outcome of low-grade lymphomas [22], their therapeutic efficacy has only recently been examined in MZL. Combination treatment with rituximab and fludarabine had been reported in two series $[9,23]$ comprising only 36 patients with non-gastric MZL. The CR rate varied from $54 \%$ to $80 \%$. In another series of 82 patients with non-gastric MZL, the purine analogue 2-chlorodeoxyadenosine \pm rituximab resulted in a $\mathrm{CR}$ rate ranging from $60 \%$ to $73 \%$ [24]. However, none of these studies compared their results with conventional regimens containing alkylating agents. Therefore, whether rituximab and purine analogues actually resulted in better outcome than alkylating agents could not be determined. In fact, the European

Table 7 Treatment results of 79 patients with non-gastric marginal zone lymphomas

\begin{tabular}{|c|c|c|c|c|c|c|c|}
\hline Treatment & Number & OR & $\mathrm{CR}$ & PR & SD & PD & Relapse \\
\hline Local treatment alone & 17 & $14 / 17(82 \%)$ & $14 / 17(82 \%)$ & $0 / 17(0 \%)$ & $2 / 17(12 \%)$ & $1 / 17(6 \%)$ & $5 / 14(36 \%)$ \\
\hline \multicolumn{8}{|l|}{ Systemic chemotherapy } \\
\hline Fludarabine containing & 28 & $25 / 28(89 \%)$ & $23 / 28(82 \%)$ & $2 / 28(7 \%)$ & $1 / 28(4 \%)$ & $2 / 28(7 \%)$ & $3 / 23(13 \%)$ \\
\hline Non-fludarabine containing & 34 & $28 / 34(82 \%)$ & $22 / 34(65 \%)$ & $6 / 34(18 \%)$ & $3 / 34(9 \%)$ & $3 / 34(9 \%)$ & $9 / 22(41 \%)$ \\
\hline \multicolumn{8}{|l|}{ Rituximab } \\
\hline Rituximab \pm chemotherapy & 25 & $23 / 25(92 \%)$ & $21 / 25(84 \%)$ & $2 / 25(8 \%)$ & $1 / 25(4 \%)$ & $1 / 25(4 \%)$ & $2 / 21(10 \%)$ \\
\hline $\begin{array}{l}\text { Non-rituximab-containing } \\
\text { chemotherapy }\end{array}$ & 37 & $30 / 37(81 \%)$ & $24 / 37(65 \%)$ & $6 / 37(16 \%)$ & $3 / 37(8 \%)$ & $4 / 37(11 \%)$ & $10 / 24(42 \%)$ \\
\hline \multicolumn{8}{|l|}{ Fludarabine and rituximab } \\
\hline Fludarabine + rituximab containing & 11 & $10 / 11(91 \%)$ & $10 / 11(91 \%)$ & $0 / 11(0 \%)$ & $0 / 11(0 \%)$ & $1 / 11(9 \%)$ & $0 / 10(0 \%)$ \\
\hline Fludarabine, non-rituximab containing & 17 & $15 / 17(88 \%)$ & $13 / 17(76 \%)$ & $2 / 17(12 \%)$ & $1 / 17(6 \%)$ & $1 / 17(6 \%)$ & $3 / 13(23 \%)$ \\
\hline Rituximab, non-fludarabine containing & 14 & $13 / 14(93 \%)$ & $11 / 14(79 \%)$ & $2 / 14(14 \%)$ & $1 / 14(7 \%)$ & $0 / 14(0 \%)$ & $2 / 11(18 \%)$ \\
\hline Non-fludarabine, non-rituximab & 20 & $15 / 20(75 \%)$ & $11 / 20(55 \%)$ & $4 / 20(20 \%)$ & $2 / 20(10 \%)$ & $3 / 20(15 \%)$ & $7 / 11(64 \%)$ \\
\hline
\end{tabular}

$O R$ overall response, $C R$ complete response, $P R$ partial response, $S D$ stable disease, $P D$ progressive disease 
Table 8 Impact of pretreatment characteristics on outcome in non-gastric marginal zone lymphomas

\begin{tabular}{|c|c|c|c|c|c|c|c|}
\hline Pretreatment characteristics & Number & OR & $\mathrm{CR}$ & PR & SD & PD & Relapse \\
\hline \multicolumn{8}{|l|}{ Disease stage } \\
\hline Stage I/II disease & 52 & $50 / 52(96 \%)$ & $44 / 52(85 \%)$ & $6 / 52(12 \%)$ & $1 / 52(2 \%)$ & $1 / 52(2 \%)$ & $13 / 44(30 \%)$ \\
\hline Stage III/IV disease & 27 & $19 / 27(70 \%)$ & $14 / 27(52 \%)$ & $5 / 27(19 \%)$ & $4 / 27(15 \%)$ & $4 / 27(15 \%)$ & $6 / 14(43 \%)$ \\
\hline \multicolumn{8}{|l|}{ Performance status } \\
\hline$\leq 1$ & 65 & $60 / 65(92 \%)$ & $53 / 65(82 \%)$ & $7 / 65(11 \%)$ & $2 / 65(3 \%)$ & $3 / 65(5 \%)$ & $13 / 53(25 \%)$ \\
\hline$>1$ & 14 & $9 / 14(64 \%)$ & $5 / 14(36 \%)$ & $4 / 14(29 \%)$ & $3 / 14(21 \%)$ & $0 / 14(0 \%)$ & $1 / 5(20 \%)$ \\
\hline \multicolumn{8}{|l|}{ IPI score } \\
\hline$<3$ & 56 & $53 / 56(95 \%)$ & $46 / 56(82 \%)$ & $7 / 56(13 \%)$ & $2 / 56(4 \%)$ & $1 / 56(2 \%)$ & $15 / 46(33 \%)$ \\
\hline$\geq 3$ & 23 & $16 / 23(70 \%)$ & $12 / 23(52 \%)$ & $4 / 23(17 \%)$ & $3 / 23(13 \%)$ & $4 / 23(2 \%)$ & $4 / 12(33 \%)$ \\
\hline
\end{tabular}

$O R$ overall response, $C R$ complete response, $P R$ partial response, $S D$ stable disease, $P D$ progressive disease

Society for Medical Oncology guideline has stated that for gastric MALT lymphoma at least, no clear evidence in the literature exists to indicate the superiority of any of these drugs [7].

Our study was retrospective so that treatment regimens were very heterogeneous. Therefore, firm conclusions are not possible. However, we had the opportunity of compar-
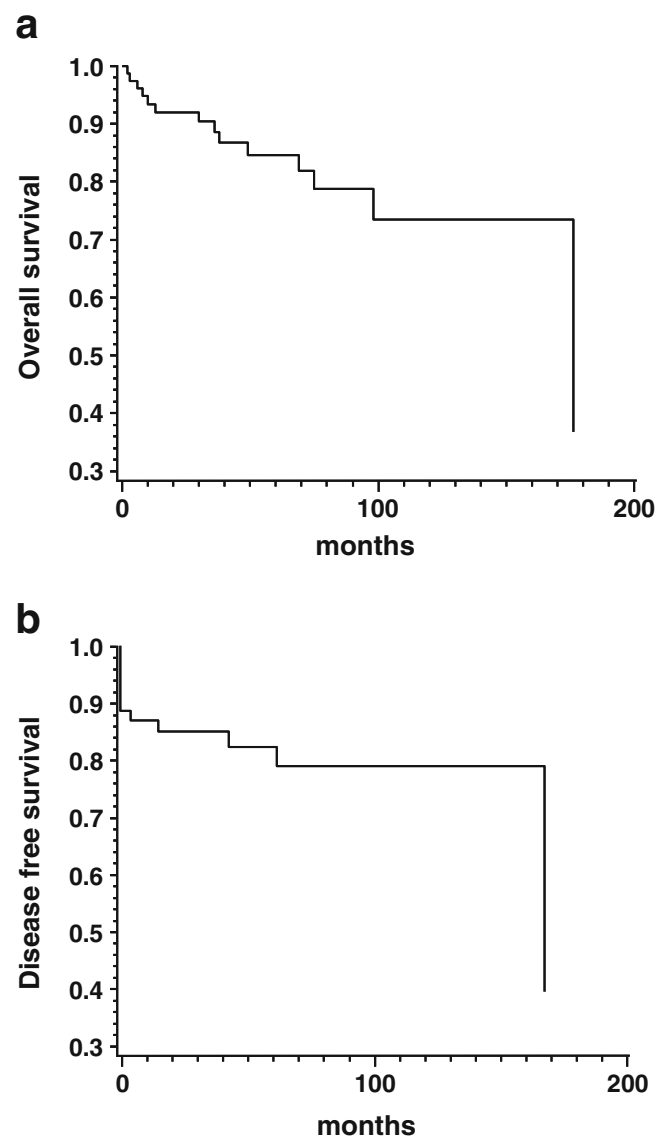

Fig. 1 Survival of patients with marginal zone lymphoma. a Overall survival. b Disease-free survival ing rituximab, fludarabine, and alkylating agent-containing regimens in the treatment of MZL. We also showed that CR rates were not different between regimens containing alkylating agents, rituximab, fludarabine, and rituximab + fludarabine. The CR rates in our study varied from $65 \%$ to $91 \%$, comparable with data reported previously from regimens containing rituximab and purine analogues $[9,10,24]$. However, we showed that relapse rates were significantly different, with regimens containing ritux$i m a b$ and fludarabine giving significantly fewer relapses. The results suggested that the depth of remission, reflecting the extent of clearance of lymphoma cells, might be better with rituximab- and fludarabine-containing regimens.

Concerns have been expressed over the use of rituximab and purine analogues in MZL. In one study, the combined use of rituximab and fludarabine resulted in significant hematologic toxicities (grade III, 77\%; grade IV, 42\%), with $15 \%$ of patients developing delayed marrow toxicity that resulted in death [9]. In this study, however, grade IV toxicity appeared to be acceptable at about $15 \%$, with treatment-related-mortality at only $2 \%$. Therefore, rituximab + fludarabine appeared to be safe in our patient population, in accordance with experience of the use of this combination in chronic lymphocytic leukemia. Another issue is the possibility of myelodysplastic syndrome related to the use of purine analogues [7], particularly fludarabine [25]. One patient in our series developed acute myeloid leukemia 6 years after receiving FND. Hence, it is important that patients who have received fludarabine should have life-long follow-up.

In conclusion, we showed that non-gastric MZL as a group showed favorable response to treatment. The use of rituximab and fludarabine reduced the relapse rate as compared with conventional chemotherapy. Therapy with rituximab and fludarabine was associated with acceptable side effects. These data obviously have to be interpreted in light of the heterogeneity of patients and treatment in this 
series. Therefore, the combination of rituximab and fludarabine should be fully evaluated systemically in prospective trials.

Conflict of interests The authors have no conflict of interests to declare.

Open Access This article is distributed under the terms of the Creative Commons Attribution Noncommercial License which permits any noncommercial use, distribution, and reproduction in any medium, provided the original author(s) and source are credited.

\section{References}

1. Isaacson PG, Piris MA, Berger F, Swerdow SH, Thieblemont C, Pitaluga S, Harris NL (2008) Splenic B-cell marginal zone lymphoma. In: Swerdlow SH, Campo E, Harris NL, Jaffe ES, Pileri SA, Stein H, Thiele J, Vardiman JW (eds) WHO classification of tumours of haematopoietic and lymphoid tissues. International Agency for Research on Cancer, Lyon, pp 185-187

2. Issacson PG, Chott A, Nakamura S, Muller-Hermelink HK, Harris NL (2008) Extranodal marginal zone lymphoma of mucosaassociated lymphoid tissue (MALT lymphoma). In: Swerdlow SH, Campo E, Harris NL, Jaffe ES, Pileri SA, Stein H, Thiele J, Vardiman JW (eds) WHO classification of tumours of haematopoietic and lymphoid tissues. International Agency for Research on Cancer, Lyon, pp 214-217

3. Campo E, Pileri SA, Jaffe ES, Muller-Hermelink HK, Nathwani BN (2008) Nodal marginal zone lymphoma. In: Swerdlow SH, Campo E, Harris NL, Jaffe ES, Pileri SA, Stein H, Thiele J, Vardiman JW (eds) WHO classification of tumours of haematopoietic and lymphoid tissues. International Agency for Research on Cancer, Lyon, pp 218-219

4. Kwong YL (2007) Predicting the outcome in non-Hodgkin lymphoma with molecular markers. Br J Haematol 137:273-87

5. Jaffe ES, Harris NL, Stein H, Campo E, Pileri SA, Swerdlow SH (2008) Introduction and overview of the classification of the lymphoid neoplasms. In: Swerdlow SH, Campo E, Harris NL, Jaffe ES, Pileri SA, Stein H, Thiele J, Vardiman JW (eds) WHO classification of tumours of haematopoietic and lymphoid tissues. International Agency for Research on Cancer, Lyon, pp $157-166$

6. Jaffe ES, Harris NL, Stein H, Isaacson PG (2008) Classification of lymphoid neoplasms: the microscope as a tool for disease discovery. Blood 112:4384-99

7. Zucca E, Dreyling M (2010) ESMO Guidelines Working Group. Gastric marginal zone lymphoma of MALT type: ESMO clinical practice guidelines for diagnosis, treatment and follow-up. Ann Oncol 21(Suppl 5):v175-176

8. Economopoulos T, Psyrri A, Fountzilas G, Tsatalas C, Anagnostopoulos A, Papageorgiou S, Xiros N, Dimopoulos MA (2008) Phase II study of low-grade non-Hodgkin lymphomas with fludarabine and mitoxantrone followed by rituximab consolidation: promising results in marginal zone lymphoma. Leuk Lymphoma 49:68-74

9. Brown JR, Friedberg JW, Feng Y, Scofield S, Phillips K, Dal Cin P, Joyce R, Takvorian RW, Fisher DC, Fisher RI, Liesveld J, Marquis D, Neuberg D, Freedman AS (2009) A phase 2 study of concurrent fludarabine and rituximab for the treatment of marginal zone lymphomas. Br J Haematol 145:741-748
10. Orciuolo E, Buda G, Sordi E, Baraté C, Galimberti S, Ciancia E, Petrini M (2010) 2CdA chemotherapy and rituximab in the treatment of marginal zone lymphoma. Leuk Res 34:184-189

11. Cervetti G, Galimberti S, Sordi E, Buda G, Orciuolo E, Cecconi N, Petrini M (2010) Significant efficacy of 2-CdA with or without rituximab in the treatment of splenic marginal zone lymphoma (SMZL). Ann Oncol 21:851-854

12. Cheson BD, Pfistner B, Juweid ME, Gascoyne RD, Specht L, Horning SJ, Coiffier B, Fisher RI, Hagenbeek A, Zucca E, Rosen ST, Stroobants S, Lister TA, Hoppe RT, Dreyling M, Tobinai K, Vose JM, Connors JM, Federico M (2007) International harmonization project on lymphoma. Revised response criteria for malignant lymphoma. J Clin Oncol 25:579-586

13. Kovács L, Szodoray P, Kiss E (2010) Secondary tumours in Sjögren's syndrome. Autoimmun Rev 9:203-206

14. Troch M, Woehrer S, Streubel B, Weissel M, Hoffmann M, Müllauer L, Chott A, Raderer M (2008) Chronic autoimmune thyroiditis (Hashimoto's thyroiditis) in patients with MALT lymphoma. Ann Oncol 19:1336-1339

15. Inagaki H, Chan JK, Ng JW, Okabe M, Yoshino T, Okamoto M, Ogawa H, Matsushita H, Yokose T, Matsuno Y, Nakamura N, Nagasaka T, Ueda R, Eimoto T, Nakamura S (2002) Primary thymic extranodal marginal-zone B-cell lymphoma of mucosaassociated lymphoid tissue type exhibits distinctive clinicopathological and molecular features. Am J Pathol 160:1435-1443

16. Zinzani PL, Magagnoli M, Galieni P, Martelli M, Poletti V, Zaja F, Molica S, Zaccaria A, Cantonetti AM, Gentilini P, Guardigni L, Gherlinzoni F, Ribersani M, Bendandi M, Albertini P, Tura S (1999) Nongastrointestinal low-grade mucosa-associated lymphoid tissue lymphoma: analysis of 75 patients. J Clin Oncol 17:1254

17. Oh SY, Kim WS, Kim SJ, Kim JS, Kim SH, Lee DH, Won JH, Hwang IG, Kim MK, Lee SI, Kim JG, Yang DH, Kang HJ, Choi CW, Park J, Choi YJ, Kim HJ, Kwon JH, Suh C, Kim HJ (2009) Relapsed or refractory nongastric marginal zone B-cell lymphoma: multicenter retrospective analysis of 92 cases. Am J Hematol 84:826-829

18. Matutes E (2007) Splenic marginal zone lymphoma with and without villous lymphocytes. Curr Treat Options Oncol 8:109-116

19. Bennett M, Schechter GP (2010) Treatment of splenic marginal zone lymphoma: splenectomy versus rituximab. Semin Hematol 47:143-147

20. Coiffier B (2005) State-of-the-art therapeutics: diffuse large B-cell lymphoma. J Clin Oncol 23:6387-6393

21. Hiddemann W, Buske C, Dreyling M, Weigert O, Lenz G, Unterhalt M (2007) Current management of follicular lymphomas. Br J Haematol 136:191-202

22. Zinzani PL, Tani M, Pulsoni A, Gobbi M, Perotti A, De Luca S, Fabbri A, Zaccaria A, Voso MT, Fattori P, Guardigni L, Ronconi S, Cabras MG, Rigacci L, De Renzo A, Marchi E, Stefoni V, Fina M, Pellegrini C, Musuraca G, Derenzini E, Pileri S, Fanti S, Piccaluga PP, Baccarani M (2008) Fludarabine and mitoxantrone followed by yttrium-90 ibritumomab tiuxetan in previously untreated patients with follicular non-Hodgkin lymphoma trial: a phase II nonrandomised trial (FLUMIZ). Lancet Oncol 9:352-358

23. Salar A, Domingo-Domenech E, Estany C, Canales MA, Gallardo F, Servitje O, Fraile G, Montalbán C (2009) Combination therapy with rituximab and intravenous or oral fludarabine in the first-line, systemic treatment of patients with extranodal marginal zone Bcell lymphoma of the mucosa-associated lymphoid tissue type. Cancer 115:5210-5217

24. Lam CC, Ma ES, Kwong YL (2005) Therapy-related acute myeloid leukemia after single-agent treatment with fludarabine for chronic lymphocytic leukemia. Am J Hematol 79:288-290

25. Ahmadi T, Schuster SJ (2009) Variations on the fludarabine, cyclophosphamide, and rituximab combination in chronic lymphocytic leukemia therapy: what have we learned? J Clin Oncol 27:479-480 